\title{
Periconceptional folic acid (FA) supplementation among pregnant women in Bosnia and Herzegovina: a cross-sectional study
}

\author{
Jasmina Djedjibegovic, ${ }^{1 *}$ Lejla Spahic, ${ }^{1}$ Aleksandra Marjanovic, ${ }^{1}$ \\ Amila Turalic, ${ }^{1}$ Aida Lugusic, ${ }^{1}$ Miroslav Sober ${ }^{1}$ \\ University of Sarajevo - Faculty of Pharmacy, Zmaja od Bosne 8, \\ 71000 Sarajevo, Bosnia and Herzegovina \\ *Corresponding author: Jasmina Djedjibegovic; \\ E-mail: djedjibegovicj@gmail.com; jasmina.djedjibegovic@ffsa.unsa.ba
}

\begin{abstract}
Folic acid (FA) supplementation is recommended for all women of childbearing age and pregnant women. Still, women's adherence to these recommendations is often low. This crosssectional survey aimed to assess FA supplementation among pregnant women in Bosnia and Herzegovina $(\mathrm{BiH})$ since no such data exist to date. Data were collected by a voluntary, anonymous, self-administered internet-based questionnaire. The inclusion criteria were current pregnancy, $\mathrm{BiH}$ origin, and $\mathrm{BiH}$ residence for at least the past 5 years. The vast majority $(82.1 \%)$ of women reported inadequate periconceptional FA supplementation, and only $26.9 \%$ reported supplementation during the critical period for neural tube closure. The use of a high dose ( $\geq 5 \mathrm{mg}$ /day) FA beyond the first trimester was reported by $9.0 \%$ of women. Women's age was significantly associated with adequate folic acid use for the prevention of neural tube defects $(\mathrm{OR}=1.207, \mathrm{p}<0.05)$. The periconceptional FA supplementation in the studied population is suboptimal. These preliminary data call for action, especially because $\mathrm{BiH}$ is a lower-middleincome country without mandatory FA food fortification program. Further research on folate dietary intake and folate status in the target group, as well as possible predictors of the low prevalence of supplementation, is recommended.
\end{abstract}

Keywords: folic acid, pregnancy, neural tube defect, preventive care, supplementation 


\section{Introduction}

Folates are a group of compounds representing different forms of vitamin B9. Vitamin B9 is an essential nutrient with a physiological role in DNA replication, amino acid synthesis, and metabolism of other vitamins. During pregnancy, folate demands increase due to the requirements of the growing fetus. Estimated general dietary folate intake is often lower than recommended for pregnant women, even in developed countries (1). Inadequate folate supply can result in anemia and peripheral neuropathy in mothers as well as congenital defects in fetuses (2). The most prominent congenital defects associated with folate deficiency are neural tube defects (NTDs), especially open spina bifida and anencephaly. Although the etiology of NTDs is not fully understood, and both genetic and environmental factors play a role, current evidence supports a strong causal relationship between NTDs prevalence and mother's folate status (3). While the genetic factors are considered as unmodifiable, environmental factors such as folate intake can be modified and thus represent an essential public health strategy. Periconceptional supplementation with folic acid (FA) has long been known to reduce the risk of NTDs in offspring (4). These findings led to widely accepted public health recommendations on periconceptional FA supplementation as well as mandatory FA fortification of staple foods, implemented in more than 80 countries thus far (5). Both of these actions resulted in a significant reduction of NTDs prevalence (5-8). Still, some countries (including the European Union, Bosnia and Herzegovina $(\mathrm{BiH})$, and most of the other non-EU countries) delay a decision on mandatory food fortification due to possible safety issues. These countries rely solely on FA supplementation in the target group (women of childbearing age and pregnant women). In both countries with mandatory food fortification and those without such program, supplementation with 400-800 $\mu \mathrm{g}$ of FA daily is recommended for all women of childbearing age and pregnant women for at least the first 12 weeks of pregnancy $(9,10)$. Higher doses $(4-5 \mathrm{mg} /$ day) are often recommended for the high-risk groups (NTD-affected previous pregnancy, first-degree relative affected by NTD, use of anticonvulsants, pregestational diabetes, body mass index (BMI) $>35 \mathrm{~kg} / \mathrm{m}^{2}$, use of folate antagonists, malabsorption syndromes) (11-13), although some professionals find this recommendation unjustified (14). Nevertheless, all available data strongly support FA supplementation (400-800 $\mu \mathrm{g} / \mathrm{day})$ at least 1 month before the last menstrual period and trough the first trimester of pregnancy. For this strategy to be effective, it would be necessary to ensure adherence with recommendations in the target groups. Unfortunately, this does not seem to be the case as a very low rate of FA supplementation, especially before pregnancy, is frequently reported (15). FA supplementation is often started only after the woman becomes aware of her pregnancy, and occasionally not even then. This finding is highly relevant since the critical period of neural tube closure extends to about 28 days after conception (16), and it is often missed due to late confirmation of pregnancy. 
$\mathrm{BiH}$ is a developing middle-income country without mandatory food fortification with FA. Furthermore, national guidelines for supplementation in pregnancy do not exist as well as any data on FA supplementation among pregnant women. Taking into consideration this framework, our survey aimed to assess periconceptional FA supplementation among pregnant women. These preliminary results are intended to serve as the baseline information for researchers, practitioners, and the public health authorities in $\mathrm{BiH}$.

\section{Methods}

This was a cross-sectional internet-based survey. The 17-item questionnaire (Table I) was prepared using Google Docs and posted online from February $23^{\text {rd }}$ to March $25^{\text {th }}$, 2015. The invitation to participate in the survey with the link to the online questionnaire was posted on a specialized web portal for expecting women and young parents (https://www.ringeraja.ba/). The main outcome variable was FA supplement use (dose and timing). The other variables (factors) were clinical (related to women's health) rather than social. Before the study, the questionnaire was piloted with 7 local pregnant women, who deemed it to be easy to complete and understand, so no further changes were required.

Table I The questionnaire items with the type of question and answer options.

Tabela I Pitanja u upitniku (tip pitanja i ponuđeni odgovori).

\begin{tabular}{|c|c|c|}
\hline Item & $\begin{array}{l}\text { Type of question } \\
\text { (open/closed) }\end{array}$ & $\begin{array}{c}\text { Answer options } \\
\text { (for closed questions } \\
\text { only) }\end{array}$ \\
\hline What is your national origin? ${ }^{*}$ & closed & "BiH" or "other" \\
\hline What is your current place of residence? ${ }^{*}$ & closed & "BiH" or "other" \\
\hline Where were you living in the past 5 years? ${ }^{*}$ & closed & "BiH" or "other" \\
\hline How old are you (years)? & open & / \\
\hline What was your pre-pregnancy body weight $(\mathrm{kg}) ?$ & open & / \\
\hline What is your current body weight $(\mathrm{kg})$ ? & open & / \\
\hline How tall are you $(\mathrm{cm}) ?$ & open & / \\
\hline $\begin{array}{l}\text { Is your current pregnancy single (one baby) or multiple } \\
\text { (more than one baby)? }\end{array}$ & closed & "Single" or "Multiple" \\
\hline In what week of pregnancy are you now? & open & / \\
\hline Is this your first pregnancy? & closed & "Yes" or "No" \\
\hline
\end{tabular}




\begin{tabular}{|c|c|c|}
\hline Item & $\begin{array}{l}\text { Type of question } \\
\text { (open/closed) }\end{array}$ & $\begin{array}{l}\text { Answer options } \\
\text { (for closed questions } \\
\text { only) }\end{array}$ \\
\hline $\begin{array}{l}\text { If this is not your first pregnancy, how long has it been } \\
\text { between the end of your previous pregnancy and the } \\
\text { beginning of your current pregnancy? }\end{array}$ & open & l \\
\hline Would you say that in general, your health is: & closed & $\begin{array}{l}\text { "excellent", "very good", } \\
\text { "good", "fair" or "poor" }\end{array}$ \\
\hline Do you have any chronic disease? & closed & "Yes" or "No" \\
\hline If you have a chronic disease(s) please state & open & / \\
\hline $\begin{array}{l}\text { Did/do you have morning sickness in your current } \\
\text { pregnancy? }\end{array}$ & closed & "Yes" or "No" \\
\hline $\begin{array}{l}\text { For any supplements you have used/are using before and } \\
\text { during your pregnancy please describe: name; brand; how } \\
\text { many tablets, capsules etc. (daily/weekly); when the use } \\
\text { started and stopped. If you did not/do not use any dietary } \\
\text { supplements please write "I do not use" }\end{array}$ & open & / \\
\hline Did you attend any education on nutrition in pregnancy? & closed & "Yes" or "No" \\
\hline
\end{tabular}

${ }^{*}$ The eliminatory questions used only to check the compliance with the predetermined eligibility criteria

* Eliminatorna pitanja korišćena isključivo za proveru ispunjenosti unapred zadatih kriterijuma za uključivanje u sudiju

The questionnaire was voluntary, anonymous, and self-completed. Therefore the implied consent was used. The study participant information section, with a clearly stated purpose of the survey, data anonymity, and consent to participate in the study by completing the questionnaire, was presented before the first question of the survey.

The sample size was calculated by using a free online tool (http://www.raosoft.com/samplesize.html) based on the desired confidence level $(95 \% \mathrm{CI})$, the tolerable margin of error, estimated population size, and estimated response distribution. Since there were no previously published data on FA supplementation among pregnant women in $\mathrm{BiH}$, we used data from our neighboring country Croatia, where the prevalence of periconceptional FA use among pregnant women (i.e. response 
distribution), was $23.6 \%$ (17). Because this distribution is highly skewed, we decided to tolerate the margin of error of 10\%. Finally, the total number of live births in $\mathrm{BiH}$ in 2014 $(\mathrm{N}=29247)$ was used as the best estimate of the population size (total number of pregnant women in the study period). The calculated sample size was 70 .

The completed questionnaires were downloaded into Microsoft Excel 2007. The participants' eligibility criteria were current pregnancy (to diminish a recall bias), $\mathrm{BiH}$ origin, and $\mathrm{BiH}$ residence for at least the past 5 years (to avoid possible foreign cultural and social influence on current supplementation practice). A total of 70 questionnaires were completed. Although all participants fulfilled the eligibility criteria, three questionnaires were excluded due to inconsistent or incomplete reporting (e.g. reporting supplement use for two months of pregnancy while reporting to be in the first month of pregnancy; omitting to report on FA use), so the final number of participants was 67 . The obtained margin of error was $10.2 \%$.

Data analysis was performed using IBM SPSS version 23 software. The results are expressed as the mean \pm standard error of the mean (SEM) or the proportion, followed by a 95\% CI in all cases. Generalized linear model ordinal logistic regression analysis was used to assess the association between dependent and independent variables. The dependent variable (FA usage) levels were: 3=adequate use (use commenced before pregnancy and continued at least till the end of the first trimester with a dose $\geq 400 \mu \mathrm{g} /$ day), $2=$ inadequate (some use, but other than adequate), $1=$ none (not used). $\mathrm{p}$ values lower than 0.05 were considered statistically significant.

The research project was approved by the Academic Council of the Faculty of Pharmacy (No. 0101-867/15 of 27.04.2015.). This study follows the principles of the Declaration of Helsinki. Survey design (non-interventional) is not considered a clinical trial under the Directive 2001/20/EC and Regulation (EU) No 536/2014.

\section{Results}

The participants mean age was 29.0 (range 22-38 years; SEM $=0.51 ; 95 \%$ $\mathrm{CI}=28.0-30.0 \%$ ) years. Women's gestational age ranged from 5 to 39 weeks, most of them in the third trimester (Table II). Previous pregnancies were reported by 19 women. Among multigravidae, the period between the end of the last pregnancy and conception of the current pregnancy (i.e. interpregnancy interval) ranged from 3 months to 10 years. The interpregnancy interval of $<24$ months, 2-5 years, and $>5$ years was recorded in 4 , 14 , and 1 cases, respectively. Pre-pregnancy BMI was calculated from self-reported data on weight and height and ranged from $18.0-29.8 \mathrm{~kg} / \mathrm{m}^{2}$. The majority of women reported self-assessed general health to be "excellent" or "very good" (Table II). Chronic health conditions were reported by 11 women and were specified in 10 cases. Specified conditions were mostly single (three with thrombophilia, two with hypertension, one with each iron deficiency anemia, asthma, thrombosis, or gestational diabetes mellitus), while 
one participant reported multiple chronic diseases (thrombophilia, Hashimoto disease, and insulin resistance). None of the participants attended education on nutrition in pregnancy.

Table II Demographic and clinical characteristics of participants $(n=67)$.

Tabela II Demografske i kliničke karakteristike učesnica u studiji (n=67).

\begin{tabular}{llrrl}
\hline Characteristic & & Count & Percent & 95\% CI \\
\hline Age (years) & $\leq 24$ & 13 & 19.4 & $10.8-30.9$ \\
& $25-29$ & 24 & 35.8 & $24.5-48.5$ \\
& $30-34$ & 22 & 32.8 & $21.8-45.4$ \\
Gestational age (weeks) & $\geq 35$ & 8 & 11.9 & $5.3-22.2$ \\
& $<13$ & 10 & 14.9 & $7.4-25.7$ \\
& $13-26$ & 22 & 32.8 & $21.8-45.4$ \\
Pre-pregnancy BMI $\left(\mathrm{kg} / \mathrm{m}^{2}\right)$ & $\leq 27$ & 35 & 52.2 & $39.7-64.6$ \\
& 18.4 & 1 & 1.5 & $0.0-8.0$ \\
Current BMI $\left(\mathrm{kg} / \mathrm{m}^{2}\right)$ & $18.5-24.9$ & 56 & 83.6 & $72.5-91.5$ \\
& $25.0-29.9$ & 10 & 14.9 & $7.4-25.7$ \\
& $18.5-24.9$ & 39 & 58.2 & $45.5-70.2$ \\
Gravidity & $25.0-29.9$ & 23 & 34.3 & $23.2-46.9$ \\
\multirow{3}{*}{ Number of fetuses } & $\geq 30$ & 5 & 7.5 & $2.5-16.6$ \\
& Primigravidae & 48 & 71.6 & $59.3-82.0$ \\
Chronic diseases & Multigravidae & 19 & 28.4 & $18.0-40.7$ \\
& One & 64 & 95.5 & $87.5-99.1$ \\
General health & More than one & 3 & 4.5 & $0.9-12.5$ \\
& Yes & 11 & 16.4 & $8.5-27.5$ \\
& No & 56 & 83.6 & $72.5-91.5$ \\
Morning sickness & Excellent & 30 & 44.8 & $32.6-57.4$ \\
& Very good & 35 & 52.2 & $39.7-64.6$ \\
& Fair & 2 & 3.0 & $0.4-10.4$ \\
& Yes & 30 & 44.8 & $32.6-57.4$ \\
& No & 37 & 55.2 & $42.6-67.4$ \\
\hline
\end{tabular}


Among the supplement users (any time during pregnancy), 10 women were using FA alone, the others using multi-component supplements (containing FA) alone, or in addition to the mono-component FA product.

Preconception use of FA was recorded in 12 women (17.9\%; 95\% CI=9.6-29.2\%), 8 of them using high doses ( $\geq 5 \mathrm{mg}$ /day). All 12 women continued with supplementation $(\geq 400 \mu \mathrm{g} /$ day) through the first trimester of pregnancy. Thus, supplementation with FA following the current recommendations was evident in only 12 women $(17.9 \%$; $95 \%$ $\mathrm{CI}=9.6-29.2 \%)$. Thirty-seven women started FA supplementation after confirmation of pregnancy (within the first trimester). Still, only 6 of them reported the start of supplementation before week 7 of pregnancy (the end of the critical period for neural tube closure). Overall, only $26.9 \%$ of women $(95 \% \mathrm{CI}=16.8-39.1 \%)$ reported the use of FA supplements in the critical period for NTDs prevention. Six women $(9.0 \% ; 95 \%$ $\mathrm{CI}=3.4-18.5 \%$ ) continued with a high dose ( $\geq 5 \mathrm{mg}$ /day) FA supplementation beyond the first trimester of pregnancy, although such use is not supported by the current recommendations. While the frequency of FA use is sharply increasing from preconception to the first trimester of pregnancy, the mean FA dose is decreasing (Table III).

Table III Folic acid (FA) use reported by study participants for different periods.

Tabela III Primena folne kiseline (FA) pre i tokom trudnoće.

\begin{tabular}{lrrrrrr}
\hline \multicolumn{1}{c}{ Period } & Count & Percent & $\mathbf{9 5 \%}$ CI & $\begin{array}{c}\text { Mean FA } \\
\text { dose } \\
(\mu \mathrm{g} / \mathbf{d a y})\end{array}$ & SEM $^{\mathbf{a}}$ & 95\% CI \\
\hline Pre-pregnancy $(\mathrm{n}=67)^{\mathrm{b}}$ & 12 & 17.9 & $9.6-29.2$ & 3528 & 647 & $2104-4950$ \\
I trimester $(\mathrm{n}=67)^{\mathrm{b}}$ & 49 & 73.1 & $60.9-83.2$ & 1878 & 305 & $1265-2491$ \\
II trimester $(\mathrm{n}=57)^{\mathrm{b}}$ & 49 & 86.0 & $74.2-93.7$ & 1176 & 219 & $737-1616$ \\
III trimester $(\mathrm{n}=35)^{\mathrm{b}}$ & 29 & 82.9 & $66.4-93.4$ & 793 & 154 & $478-1109$ \\
\hline
\end{tabular}

${ }^{a}$ SEM, standard error of the mean

${ }^{\mathrm{b}}$ All available data are shown (e.g. data for the pre-pregnancy period include the total number of participants who reported folic acid use before pregnancy irrespective of their current pregnancy stage)

${ }^{a}$ SEM, standardna greška aritmetičke sredine

${ }^{\mathrm{b}}$ Prikazani su svi dostupni podaci (npr. podaci za period pre trudnoće uključuju ukupan broj žena koje su prijavile primenu folne kiseline pre trudnoće nezavisno od perioda trudnoće u momentu anketiranja) 
A statistically significant positive association was found between adequate periconceptional FA supplements intake and women's age (Table IV).

Table IV Association of folic acid (FA) usage and independent variables $(n=67)$.

Tabela IV Povezanost primene folne kiseline (FA) i nezavisnih varijabli $(n=67)$.

\begin{tabular}{lccc}
\hline Covariates/factors & OR & 95\% CI & p-value \\
\hline Age & 1.207 & $1.028-1.416$ & 0.021 \\
Gravidity & 2.476 & $0.669-9.166$ & 0.174 \\
Number of fetuses & 12.765 & $0.967-168.5$ & 0.053 \\
Chronic diseases & 0.605 & $0.136-2.698$ & 0.510 \\
Morning sickness & 1.472 & $0.471-4.607$ & 0.506 \\
\hline Dependent variable (FA usage) levels: $3=$ adequate use (use commenced before pregnancy and continued at \\
least till the end of the first trimester with a dose $\geq 400 \mu$ g/day), 2=inadequate (some use, but other than \\
adequate), 1= none (not used) \\
Nivoi zavisne varijable (primena FA): $3=$ adekvatna primena (primena započeta pre trudnoće i nastavljena \\
najmanje do kraja prvog trimestra u dozi $\geq 400 \mu \mathrm{g} /$ dan), $2=$ neadekvatna primena (primena različita od \\
adekvatne), 1=bez primene (suplement nije korišćen)
\end{tabular}

\section{Discussion}

The FA supplement usage any time during pregnancy was reported by $88.1 \%$ of women $(95 \% \mathrm{CI}=77.8-94.7 \%)$ while preconception $\mathrm{FA}$ use was reported by $17.9 \%$ of women $(95 \% \mathrm{CI}=9.6-29.2 \%)$. A similar rate of periconceptional FA supplementation is commonly found in other studies from this European region, for example in Zadar County, Croatia (23.6\% pre-pregnancy, $75.2 \%$ during pregnancy) (17), Italy (23.5\% prepregnancy, $84 \%$ any time before and/or during pregnancy) (18), and in Spain (22.8\% prepregnancy, $85.8 \%$ in the first trimester) (19). 
Among the FA supplement users, daily FA dose $\geq 800 \mu \mathrm{g}$ was used most frequently in the preconception period and by about $40 \%$ of women during pregnancy. This is an important finding considering that data from a recent randomized trial show that a daily dose of $800 \mu \mathrm{g}$ would be more appropriate than $400 \mu \mathrm{g}$ if the NTDs protective folate concentration was to be reached within 4-8 weeks (20). Thus a daily dose of $800 \mathrm{mg}$ should be particularly recommended for women with low folate status who start with supplementation right at the periconceptional period and those who reside in countries without mandatory food fortification. Unfortunately, we were unable to find data on folate status in women of reproductive age in $\mathrm{BiH}$, so further research in this field is required. However, food fortification with FA is voluntary and not widespread in $\mathrm{BiH}$. Furthermore, Gicevic et al. found that daily folate intake was lower than the recommended average requirement $(250 \mu \mathrm{g}$ dietary folate equivalents, DEF) in $66.9 \%$ adult female participants in their dietary survey recently conducted in $\mathrm{BiH}$ (21). Overall, one can assume that low folate levels can be expected in women of reproductive age in $\mathrm{BiH}$. If this is indeed the case, then perhaps $800 \mu \mathrm{g}$ of FA should be the recommended daily dose in $\mathrm{BiH}$, especially bearing in mind that the periconceptional supplementation rate is very low. In that context, our results would mean that at least $50 \%$ of women are taking FA in a dose lower than needed.

Interestingly, $9 \%$ of women in our study $(95 \% \mathrm{CI}=3.4-18.5 \%)$ continued with the use of high-dose FA beyond the first trimester of pregnancy. Data from Spain show an even higher rate (17\%) of high-dose FA use beyond the periconceptional period (19). High doses of FA (4-5 mg/day) are still recommended in some official guidelines for women in high-risk groups, yet none of the guidelines recommend that high FA doses should be continued after the first 12 weeks of pregnancy $(11,12)$. While there is no scientific evidence to support high FA doses in late pregnancy, the emerging new evidence draws attention to the possible adverse effects of such FA use (22-27). Furthermore, some authors have also called for a revision of the recommendation on high dose FA supplementation even in high-risk groups since it was based on more than 30 years old study that failed to be confirmed by more recent research (14). Still, high dose FA supplementation may be useful if it is commenced just at the very beginning of pregnancy, which is often the case (17-19). One possible solution to this scenario was already suggested by Amitai and Koren, who recommended $5000 \mu \mathrm{g} /$ day of FA for two months, from pregnancy recognition (typically week 5 of pregnancy) throughout the first trimester (13). Another regime was proposed by Bailey and Ayling: short term (five doses, every 12 hours) supplementation with $7500 \mu \mathrm{g}$ of the bioactive form of folate, 5-methyltetrahydrofolate (5-MTHF) and subsequent supplementation with $800 \mu \mathrm{g} / \mathrm{day}$ of 5-MTHF (28). This dosing regimen was shown to reach the target serum folate level almost immediately in nearly all tested women and to maintain it adequate throughout the study period of 19 days. In comparison to this, supplementation with the FA in an equivalent dose resulted in reaching the target folate levels in only about $45 \%$ of study 
subjects within the same time frame. The suggested dosing regimen with 5-MTHF was shown to replete folate stores more rapidly and uniformly in comparison to FA and without exposure to high levels of unmetabolized FA, which was related to possible adverse effects in the recent studies. To be widely accepted, these data should still be confirmed in more randomized clinical trials. The debate on optimal timing, dosage, and even form of FA is still vivid among researchers and health professionals, but its analysis is beyond the scope of this paper. In our sample, only one woman used a supplement that contained 5-MTHF, while in all other cases folic acid was the chemical form of the vitamin in a supplement.

Official BiH guidelines for FA supplementation are yet to be developed. This would require a prior nation-wide study of the folate status and dietary folate intake in pregnant and women of childbearing age. Further studies are also needed to reveal the possible other underlying reasons for inadequate folic acid supplementation that could provide the basis for meaningful and effective actions to be taken. We found the older pregnant women to be more likely to adequately use periconceptional FA supplementation relatively to the younger ones. The same finding was reported from a recent Japanese study (29), but the authors also reported on a negative association between multiparity and periconceptional FA use, which was not the case in our study. Higher maternal age and lower parity were identified as positive predictors of periconceptional FA use in a large Italian study (18), but again the authors found that having a chronic disease was also a positive predictor while our study did not show the same. Similar discrepancies are not uncommon in literature, indicating that there is still a need for research on this topic. However, we can conclude from our data that further actions should primarily target younger women $(<30$ years of age).

Our results also show that there are still opportunities for further enhancements when it comes to maternal-fetal care. For example, none of the women in our sample, including those with reported chronic health conditions or overweight had any dietary counseling, probably because it is currently not a standard practice in $\mathrm{BiH}$. Four women (6\%) reported interpregnancy interval $<24$ months; none of them was using FA supplement before their current pregnancy, two of them starting supplementation in the first trimester (doses 300 and $400 \mu \mathrm{g} /$ day), one in the second trimester ( $800 \mu \mathrm{g} /$ day) and one woman was using a multivitamin supplement that did not contain FA. Women with short interpregnancy intervals are at higher risk of nutrients depletion, and they should at least get credible dietary advice.

\section{Conclusions and recommendations}

The results of our study show a low prevalence ( $<30 \%$ with $95 \%$ confidence) of adequate periconceptional FA supplementation concerning both timing and dosage. Data also show a rather variable FA supplementation practice (from non-users to high-dose 
users throughout pregnancy). Further studies on the underlying reasons for this inconsistency (besides evident lack of official guidelines), as well as folate dietary intake and folate status assessment among women of reproductive age in $\mathrm{BiH}$, are warranted. FA supplement use was significantly associated with women's age, but not with gravidity, morning sickness, chronic conditions, and the number of fetuses. Considering our results together with what is already known (FA pharmacokinetics and target levels, local food fortification practice) and what is unknown (dietary folate intake in pregnant and women trying to conceive, factors affecting FA supplementation in $\mathrm{BiH}$ women), at this point it seems prudent to recommend daily supplementation with $800 \mu \mathrm{g}$ of FA that should be intensively promoted, primarily among younger women. Official national guidelines on supplementation for women who are pregnant or planning pregnancy should be developed, encompassing both the local conditions and the recent scientific evidence. To provide evidence for guidelines and national policies in this field, further research is needed and should be supported.

\section{Acknowledgments}

The authors would like to sincerely thank all women who took part in this survey.

\section{References}

1. Martiniak Y, Heuer T, Hoffmann I. Intake of dietary folate and folic acid in Germany based on different scenarios for food fortification with folic acid. Eur J Nutr. 2014;54(7): 1045-1054.

2. Bailey LB, Berry RJ. Folic acid supplementation and the occurrence of congenital heart defects, orofacial clefts, multiple births, and miscarriage. Am J Clin Nutr. 2005; 81(Suppl. 5):1213S-1217S.

3. Greene ND, Copp AJ. Neural tube defects. Annu Rev Neurosci. 2014;37:221-242.

4. Hodgetts VA, Morris RK, Francis A, Gardosi J, Ismail KM. Effectiveness of folic acid supplementation in pregnancy on reducing the risk of small-for-gestational age neonates: a population study, systematic review and meta-analysis. BJOG 2015;122(4):478-490.

5. Chrysanthopoulou E, Karampela I, Diakaki C, Theodorakopoulou M, Armaganidis A. (2018) Mandatory folic acid food fortification to prevent neural tube defects: The pro or con debate. Am J Intern Med. 2018;6(4):66-72.

6. Crider KS, Bailey LB, Berry RJ. Folic acid food fortification-its history, effect, concerns, and future directions. Nutrients. 2011;3(3):370-384. 
7. Rosenthal J, Casas J, Taren D, Alverson CJ, Flores A, Frias J. Neural tube defects in Latin America and the impact of fortification: a literature review. Public Health Nutr. 2013;17(3):537-550.

8. Garrette GS, Bailey LB. A public health approach for preventing neural tube defects: folic acid fortification and beyond. Ann NY Acad Sci. 2018;1414(1):47-58.

9. World Health Organization (2016) WHO Recommendations on antenatal care for a positive pregnancy experience. Geneva: WHO. Available from: https://www.who.int/reproductivehealth/publications/maternal_perinatal_health/anc-positivepregnancy-experience/en/

10. US Preventive Services Task Force. Folic acid supplementation for the prevention of neural tube defects: US Preventive Services Task Force Recommendation Statement. JAMA 2017;317(2):183189.

11. Working Group on Best Practice in Maternal-Fetal Medicine International Federation of Gynecology and Obstetrics (FIGO). Best practice in maternal-fetal medicine. Int J Gynecol Obstet. 2015;128(1):80-82.

12. American College of Obstetricians and Gynecologists. ACOG Committee Opinion Number 762 : Prepregnancy counseling. Obstet Gynecol. 2019;133(1): e78-e89.

13. Amitai Y, Koren G. The folic acid rescue strategy high-dose folic acid supplementation in early pregnancy. JAMA Pediatr. 205;169(12):1083-1084.

14. Dolin CD, Deierlein AL, Evans MI. Folic acid supplementation to prevent recurrent neural tube defects: 4 milligrams is too much. Fetal Diagn Ther. 2018;44(3):161-165.

15. Toivonen KI, Lacroix E, Flynn M, Ronksley PE, Oinonen KA, Metcalfe A, et al. Folic acid supplementation during the preconception period: A systematic review and meta-analysis. Prev Med. 2018;114:1-17.

16. Botto LD, Moore CA, Khoury MJ, Erickson JD. Neural-tube defects. N Engl J Med. 1999;341(20):1509-1519.

17. Vitale K, Sović S, Milić M, Balorda Lj, Todorović G, Uhoda B. What Zadar county parturient women know of folic acid and how much they use it. Med Jad. 2011; 41(3-4):95-103.

18. Nilsen RM, Leoncini E, Gastaldi P, Allegri V, Agostino R, Faravelli F et al. Prevalence and determinants of preconception folic acid use: an Italian multicenter survey. Ital J Pediatr. doi: 10.1186/s13052-016-0278-z.

19. Navarrete-Muñoz EM, Valera-Gran D, García de la Hera M, Gimenez-Monzo D, Morales E, Julvez $\mathrm{J}$, et al. Use of high doses of folic acid supplements in pregnant women in Spain: an INMA cohort study. BMJ Open. 2015;5(11):e009202. doi: 10.1136/bmjopen-2015-009202.

20. Obeid R, Schön C, Wilhelm M, Pietrzik K, Pilz S. The effectiveness of daily supplementation with 400 or $800 \mu \mathrm{g} /$ day folate in reaching protective red blood folate concentrations in non pregnant women: a randomized trial. Eur J Nutr. 2018;57(5):1771-1780.

21. Gicevic S, Gaskins AJ, Fung TT, Rosner B, Sabanovic E, Gurinovic M, et al. Fueling an epidemic of non-communicable disease in the Balkans: a nutritional survey of Bosnian adults. Int J Public Health. 2019;64(6):873-885. 
22. Wang S, Ge S, Zhu B, Xuan Y, Huang K, Rutayisire E, et al. Maternal continuing folic acid supplementation after the first trimester of pregnancy increased the risk of large-for-gestational-age birth: A population-based birth cohort study. Nutrients. 2016;8(8):493. doi:10.3390/nu8080493.

23. Zhu B, Ge X, Huang K, Mao L, Yan S, Xu Y, et al. Folic acid supplements intake in early pregnancy increases risk of gestational diabetes mellitus: evidence from a prospective cohort study. Diabetes Care. 2016;39(3):e36-7. doi:10.2337/dc15-2389.

24. Zetstra-van der Woude PA, De Walle HEK, Hoek A, Bos HJ, Boezen HM, Koppelman GH, et al. Maternal high-dose folic acid during pregnancy and asthma medication in the offspring. Pharmacoepidemiol Drug Saf 2014;23(10):1059-1065.

25. Wang T, Zhang HP, Zhang X, Liang ZA, Ji YL, Wang G. Is folate status a risk factor for asthma or other allergic diseases? Allergy Asthma Immunol Res. 2015;7(6):538-546.

26. McStay CL, Prescott SL, Bower, Palmer DJ. Maternal folic acid supplementation during pregnancy and childhood allergic disease outcomes: A question of timing? Nutrients. 2017;9(2):123. doi:10.3390/nu9020123.

27. Wiens D, DeSoto MC. Is high folic acid intake a risk factor for autism?-A Review. Brain Sci. 2017;7(11):149. doi:10.3390/brainsci7110149.

28. Bailey SW, Ayling JE. The pharmacokinetic advantage of 5-methyltetrahydrofolate for minimization of the risk for birth defects. Sci Rep. 2018;8(1):4096. doi:10.1038/s41598-018-22191-2.

29. Yamamoto S, Wada Y. Awareness, use and information sources of folic acid supplementation to prevent neural tube defects in pregnant Japanese women. Public Health Nutr. 2018;21(4):732-739. 


\title{
Perikoncepcijska primena folne kiseline kod trudnica u Bosni i Hercegovini: studija preseka
}

\author{
Jasmina Đeđibegović, ${ }^{1 *}$ Lejla Spahić, ${ }^{1}$ Aleksandra Marjanović, ${ }^{1}$ \\ Amila Turalić, ${ }^{1}$ Aida Lugusić, ${ }^{1}$ Miroslav Sober ${ }^{1}$
}

Univrzitet u Sarajevu - Farmaceutski fakultet, Zmaja od Bosne 8, 71000 Sarajevo, Bosna i Hercegovina

*Autor za korespondenciju: Jasmina Đeđibegović;

E-mail: djedjibegovicj@gmail.com; jasmina.djedjibegovic@ffsa.unsa.ba

\begin{abstract}
Kratak sadržaj
Redovna suplementacija folnom kiselinom (FA) preporučuje se svim ženama fertilne dobi i trudnicama. Istraživanja pokazuju da je primena ovih preporuka u praksi nezadovoljavajuća. Cilj ove studije preseka je bio ispitati praksu FA suplementacije među trudnicama u Bosni i Hercegovini $(\mathrm{BiH})$ s obzirom na to da takvi podaci trenutno nisu dostupni. Podaci su prikupljeni putem anonimnog elektronskog upitnika, a učešće u anketi je bilo dobrovoljno. U studiju su uključene trudnice poreklom iz $\mathrm{BiH}$ i prebivalištem u $\mathrm{BiH}$ najmanje poslednjih 5 godina. Neadekvatna prekoncepcijska suplementacija je primećena kod većine ispitanica (82.1\%), a samo $26.9 \%$ ispitanica je prijavilo suplementaciju tokom kritičnog perioda pre zatvaranja neuronske cevi u ploda. Primenu visokih doza ( $\geq 5 \mathrm{mg}$ /day) FA nakon prvog trimestra je uočena kod $9.0 \%$ ispitivanih trudnica. Uzrast ispitanica je bila značajno povezana sa adekvatnom FA suplementacijom $(\mathrm{OR}=1.207, \mathrm{p}<0.05)$. Rezultati istraživanja ukazuju na suboptimalnu perikoncepcijsku suplementaciju u ciljnoj grupi, što je posebno značajno imajući u vidu da je BiH srednje razvijena zemlja bez programa obaveznog obogaćivanja hrane FA. Potrebna su dalja istraživanja o prehrambenom unosu i statusu folata u ciljnoj grupi, kao i mogućih prediktora neadekvatne suplementacije.
\end{abstract}

Ključne reči: folna kiselina, trudnoća, defekt neuronske cevi, prevencija, suplementacija 